\title{
Development of liability framework for genetically modified food: problems and perspectives under international law and Indian law
}

\section{S.K. Bala Shanmugam}

Tamil Nadu National Law University, Trichy, Tamil Nadu 620027, India

Email: sksam2008@gmail.com

\section{S.R. Subramanian* and M. Padmavati}

\author{
Rajiv Gandhi School of Intellectual Property Law, \\ Indian Institute of Technology Kharagpur, \\ West Bengal, 721-302, India \\ Email: essaresm@gmail.com \\ Email: mpadma@rgsoipl.iitkgp.ac.in \\ *Corresponding author
}

\begin{abstract}
The introduction of GM foods in the world market has continued to raise public concerns touching upon, health, legal, social, ethical and environmental issues. Especially, the issue of contamination is considered as a significant threat at many stages of development of GM food. Moreover, contamination becomes an issue not only at the stage of import but also at the stage of internal distribution of products within the country. In this connection, the current study examines the extent of development of liability framework for GM food and derivatives both under the international law and under the Indian law. In particular, it analyses the existing setup of liability framework in respect of GM food in India. Finally, it suggests that the Indian legislature must take into account the liability framework under either by way of amendment in the existing FSS Act, 2006, or by bringing in a dedicated law to deal with the potential harm in relation to GM food and derivatives.
\end{abstract}

Keywords: liability and redress; contamination; India; FSS Act 2006; genetically modified food; precautionary principle; product liability.

Reference to this paper should be made as follows: Shanmugam, S.K.B., Subramanian, S.R. and Padmavati, M. (2020) 'Development of liability framework for genetically modified food: problems and perspectives under international law and Indian law', Int. J. Private Law, Vol. 9, No. 4, pp.201-230.

Biographical notes: S.K. Bala Shanmugam is currently working as an Assistant Professor at the Tamil Nadu National Law University, Trichy, Tamil Nadu and has previously worked as a Research Scholar at the Rajiv Gandhi School of Intellectual Property Law, Indian Institute of Technology, Kharagpur.

S.R. Subramanian is working as an Assistant Professor at the Rajiv Gandhi School of Intellectual Property Law, Indian Institute of Technology, Kharagpur. 
M. Padmavati is working as a Professor and Dean at the Rajiv Gandhi School of Intellectual Property, Indian Institute of Technology, Kharagpur.

\section{Introduction}

The public concerns about genetically modified (GM) food and crops are not new. In fact, the potential health concerns of GM foods were advanced as early as 1994, since the inception of GM food. ${ }^{1}$ To some extent, these concerns have also become a reality in 1999, when GM foods were commercialised. ${ }^{2}$ Also, reports claimed that rats fed with GM foods have developed a cancerous cell growth in the intestinal tract. ${ }^{3}$ In addition to this, the scientists have also reportedly identified the possible allergens which might cause adverse health effects after introduction of GM food into the food supply chain. ${ }^{4}$ The health apprehensions of GM food were aggravated with the break of news of first human death caused by ingestion of GM food, which was reported at the Madrid Hospital, Spain in the year 2015. ${ }^{5}$ Medical examiners and forensic experts of this case have identified that the cause of death is due to the consumption of tomatoes containing fish-related genes and antibiotic resistant genes which had prevented the development of white blood corpuscles (WBC). ${ }^{6}$

There are also instances to show that the safety concerns of GM food were realised for potential impact and risk(s) in several other countries. For example, a study conducted by the Department of Food Science and Technology, University of Nebraska identified that the gene developed from Brazilian Nuts when introduced to GM soybean causes allergies to human beings. ${ }^{7}$ Also, there are instances to show that a high chance of contamination of conventional food with that of GM food in the process of trade. ${ }^{8}$ The GM contamination register, a documentation service maintained by Greenpeace and Gene Watch UK have found contamination in three internationally cultivated GM food and feed crops, oilseed rape, soya and maize, since 1997. ${ }^{9}$

Another problem arising out was the loss of certification by the organic farmers because of contamination of GM ingredients with that of conventional food. In this connection, it is apt to note that the case of Marsh v. Baxter ${ }^{10}$, where the appellant lost for around $70 \%$ of Organic Certification from National Association for Sustainable Agriculture (NASAA) during the period between 29th December 2010 and November 2013 due to GM contamination and the loss to the tune of US $\$ 80,000 .{ }^{11}$ Moreover, the US case of Star Link (GM Corn) ${ }^{12}$ brought to the fore an interesting issue in GM contamination. While research and development of the GM corn are allowed only for animal feed and not for human consumption, the issue of contamination was identified in the conventional variety of corn during the process of trade. It is significant to note that this may raise issues in the determinations of liability. The case of contamination is not only restricted to the organic farmers, and to the farm fields, but also extended to the health issues of consumers. For instance, in Colleen Gallagher v. Chipotle Mexican Grill Inc. ${ }^{13}$, a class action suit was filed by a Californian woman before the United States District Court of Northern California claiming that the food served at the restaurant contained ingredients of GM, while the advertisement claimed that the product was GM free. ${ }^{14}$ 
Therefore, the contamination becomes a significant threat at all stages of GM food production to consumption. Therefore, the present study has been attempted to examine the extent of development of liability framework for GM food and derivatives at the international perspective and also in selected jurisdictions with special reference to India. For this purpose, the first section examines the channelling of liability which is an important phenomenon for fixation of liability. Section 2 examines the international liability framework whose general structure stands as a starting point for determining liability and redress mechanism for GM food and derivatives. Then the liability framework that is developed across various jurisdictions such as European Union, Brazil, India, China and South Africa have been analysed in Section 3.

Section 4 describes more in detail the review of the liability framework that exists in other domestic legislations and the enforcement agencies in India. Further, the analysis has been carried out in the Food Safety and Standards Act, 2006 to identify the institutional development for regulating GM foods and its derivatives in Section 5. Finally, it presents suggestions are given on how to combat with the issues and to correct the imbalance from a legal parlance.

\section{Determination of liability}

The channelling of liability is an important phenomenon for determining the liability for damage arising out of genetically modified organisms (GMOs) including GM food and derivatives. $^{15}$ It is appropriate to discuss it under two heads, i.e., industry and government. ${ }^{16}$

\subsection{Industrial liability}

In general, the manufacturers/producers is always interested in bringing a new product for the consumers by making certain adjustments in the food supply chain to capture market. ${ }^{17}$ As per Article 7 of the Cartagena Protocol on Biosafety, the manufacturers' are under obligation to ensure the safety of the products and free from defects. ${ }^{18}$ If the producers fail to consider appropriate measures to ensure a safe transfer of product, then there might be a chance of contamination with that of conventional counterparts. ${ }^{19}$ In this case, the producers are made liable to compensate the loss occurred to the consumers and the procedures as elaborated in Article 12 of the Nagoya-Kuala Lumpur Supplementary Protocol on Liability and Redress to the Cartagena Protocol on Biosafety. ${ }^{20}$

Further, in the case of international trade in GM food and derivatives, there are many parties involved such as manufacturers, exporters, importers, distributors and retailers, etc. In such scenario, the developer is primarily liable, or if he is found to be out of the jurisdiction, then the liability must be fixed on any of the parties listed as an operator. ${ }^{21}$ For instance, the Basel Protocol sets out a liability mechanism for the notifier, disposer, exporter, importer and as well as re-importer of hazardous wastes. ${ }^{22}$ Moreover, the Cartagena Protocol on Biosafety also includes the private entities as parties. ${ }^{23}$ 


\subsection{Governmental liability}

Apart from the industrial liability, the Government holds a decisive role in managing and determining the liability for the GM food and derivatives. Therefore, the need for governmental intervention is highly appreciated in the form of regulations. The regulatory actions of the governmental authorities must focus on the liability to a certain extent. It is because the GM technology is a novel technology that does not carry sufficient scientific certainty to determine the mechanism of liability. ${ }^{24}$ The Basel Convention on liability also substantiates that the state responsibility in many decisions of environmental damage. Adding to this, the International Law Commission (ILC) widely discussed the aspects of state responsibility in relation to the internationally wrongful acts in the year 2001. ${ }^{25}$ Also, the ILC recognised the private conduct of the state, but the rules of liability related to damage arose in respect of transboundary trade was not explicitly mentioned. ${ }^{26}$ Article 2 of the draft articles of the ILC indicates that the fault need not be expressed in the case of international responsibility; rather the determination is left to primary rules on state obligation. ${ }^{27}$ Therefore, the liability of GM foods could be managed only by the joint initiative of government and industry.

\section{Development of principles of liability at international law}

This section examines international liability framework whose general structure provides an appropriate starting point for liability and redress in dealing with damages arising out of introduction and import of GM food and derivatives.

\subsection{Cartagena Protocol on Biosafety and its supplementary protocol}

The Cartagena Protocol on Biosafety was the first international environmental agreement modelled after the Basel Convention, ${ }^{28}$ to ensure the safe handling, package and distribution of living modified organisms (LMOs) with the primary focus on the transboundary trade of LMOs including GMOs and GM food and derivatives. ${ }^{29}$ Though the agreement has been successful in certain regulatory innovations in the case of GM food and derivatives, the language of the agreement is silent in the case of substantial provisions of standards of liability and redress mechanism to deal with the damages arising out of import or export of GM Foods and derivatives. But the legal obligation to develop the rules on liability and redress concerning GM food was found in Article 27 of the Cartagena Protocol on Biosafety which read as follows:

\footnotetext{
"The Conference of the Parties serving as the meeting of the Parties to this Protocol shall, at its first meeting, adopt a process with respect to the appropriate elaboration of international rules and procedures in the field of liability and redress for damage resulting from transboundary movements of living modified organisms, analysing and taking due account of the ongoing processes in international law on these matters, and shall endeavour to complete this process within four years."
}

The above clause of the Cartagena Protocol on Biosafety enabled the parties to formulate procedures relating to liability and redress to deal with damage arising out of import and export of GM food and derivatives. ${ }^{30}$ This particular clause necessitates the importance of the development of the liability provisions under a single legislation to deal with the 
damage arose in the transboundary trade of GM food and derivatives. ${ }^{31}$ After of discussion under the purview of Cartagena Protocol on Biosafety, the Nagoya-Kuala Lumpur Supplementary Protocol on Liability and Redress (N-KL Protocol) was negotiated for dealing with the issues of liability concerning LMOs including GMOs and GM foods. ${ }^{32}$ The principal objective of the N-KL Protocol is to lay internationally agreed rules and procedures to prevent and remedy damage to the biodiversity for the injury caused by the transboundary movement of LMOs. ${ }^{33}$ The salient feature of the N-KL Supplementary Protocol includes response measure, administrative approach, civil liability and state responsibility. ${ }^{34}$

According to Article 5 of the N-KL Protocol, the member-countries is authorised to formulate response measures for the operators to keep informed about the incidents of damage caused by the transboundary movement of GM foods to the designated competent authority. ${ }^{35}$ The liability was upon the Competent Authority to consider appropriate measures to evaluate the cost of damage. Though it may be regarded as a fundamental phenomenon under the aegis of N-KL Protocol to protect biodiversity, but it offers a different fashion in dealing with damage such as personal injury or property damage. $^{36}$ Therefore, the food business operator (FBO) as well as the competent authority holds an additional responsibility to consider the procedures for dealing with the damage. In this connection, the response measures offered under the particular clause will be a full choice of action for the countries to develop a mechanism of defensive or restorative in their domestic legislations. When there are sufficient likelihood of damage or at the occurrence of harm, the member-countries shall fix the procedures for the operator to take significant action to deal with the loss. ${ }^{37}$ In this way, the operator has to undertake three-pronged action such as reporting the incident to the competent authority, evaluate the damage and to consider appropriate measures mentioned in Article 5.1. From the language of Article 5.3, it is clear that the operator has to take appropriate measures to avoid the occurrence of the damage during any sufficient likelihood of damage. In the case of failure to discharge his duties, the Competent Authority must enter into operation and formulate a suitable procedure to deal with the damage and to remedy victims as envisaged under Article 5.4. In such actions, the competent authority is entitled to receive the expenses incurred by them.

It is a well-established principle that every country shall safeguard its boundaries from the harm caused by neighbouring countries. ${ }^{38}$ Therefore, the state is accountable for every kind of damage caused during the transportation of GM food across its territories. An attempt has been made at the international level to introduce a uniform liability regime in the form of civil liability to deal with the damage arising out of the transboundary trade in GM food and its derivatives through the Cartagena Protocol on Biosafety on the contrary, the member-countries must formulate the standards of liability in the domestic laws on the basis of the economic, social, and other political perspectives of the country. In this connection, Article 12 of the N-KL Protocol enumerates the principle of civil liability through the judicial system of a country which considers the attachment of responsibility for any damage through the civil remedies. ${ }^{39}$ The civil remedies may be obtained by the victims by way of writing petition to the designated administrative authorities. ${ }^{40}$ It is a kind of private litigation, where the injured party files a suit against the offenders claiming damages without including the 'State' as a party. ${ }^{41}$ The relief sought by the claimant must be in two forms; either it can be a monetary compensation or an injunction to restrain the activities of the defendant. ${ }^{42}$ It reflects the 
principle that the injured person has the right of recourse against the person accountable for the damage in their national legal system. ${ }^{43}$

According to the civil liability doctrine as found in Article 12 of the N-KL Protocol, every member country shall formulate rules and procedures of liability to deal with the injury arising out of transboundary trade of GM food and derivatives. The incorporation of standards of liability may be, by way of amendment to the existing legislation or through the introduction of specific laws to deal with the damage. ${ }^{44}$ In certain circumstances, the combination of both in general and specific laws will serve the purpose. $^{45}$ Though the N-KL Protocol deals with the loss concerning the transboundary trade of GM food and derivatives, the standards of liability for damage occurred at the domestic production needs to be developed. Moreover, the attempt of N-KL Protocol failed in its uniform liability regime because the standards of liability are bound to differ. $^{46}$ Even though the N-KL Protocol was unable to create rules, the obligation for transboundary trade remains an issue at the international arena. Moreover, there is a lacuna in the N-KL Protocol in the determination of liability or parties to the suit.

Many international agreements contain provisions calling for the development of liability regimes, but so far few systems have been developed. Most international agreements in the area of transboundary environmental damage utilise a civil liability regime where private parties predominantly control the activities at issue. The definition of GMOs included in the Cartagena Protocol on Biosafety includes the activity concerning LMOs intended for the direct use of food, feed or processing (FFP). ${ }^{47}$ The damages caused by processed GM products are also relevant in the definitional clause which is excluded from the scope of damage. ${ }^{48}$ The adoption of individual liability regimes in every GM importing countries will be the necessary complement to the international law system. ${ }^{49}$ It is because of the international agreements and in particular Article 5 of the N-KL Protocol provides freedom for the countries to develop their standards in dealing with damages arising out of introduction or import of GM food and derivatives. ${ }^{50}$ In addition to the development of N-KL Protocol, there is a possibility for the development of principles of liability in the legislations of developed and well as developing countries. In this aspect, the domestic legislations of certain developing countries needs to be analysed to bring out the extent of development of liability mechanism in dealing with damages concerning GM food and derivatives. The analysis is done in Sections 4 and 5.

\subsection{Precautionary measure and leading judicial pronouncements}

The precautionary principle has become the fundamental component of international environmental policy. ${ }^{51}$ It was proclaimed at the United Nations Conference on Environmental and Development, popularly known as the Rio Declaration in the year 1992. More particularly Principle 15 of the Rio Declaration reads as follows: ${ }^{52}$

"In order to protect the environment, the precautionary principle shall be widely applied by States according to their capabilities. Where there are threats of serious or irreversible damage, lack of full scientific certainty shall not be used as a reason for postponing cost-effective measures to prevent environmental degradation."

This principle has been widely accepted to protect the environment and to prevent damage concerning GMOs where there is an existence of scientific uncertainty. Though 
the precautionary principle is hailed as one of the essential components of the Rio Declaration and the Cartagena Protocol on Biosafety (Biosafety Protocol), the adoption and justification is still unsettled at the international parlance. ${ }^{53}$ On the other hand, the precautionary approach is considered to be a significant feature of the Biosafety Protocol in dealing with GM foods, Further, in view of absence of conclusive evidence relating to the long-term effect of GM foods on human health. It is most appropriate for the developing country to adopt a precautionary approach.

The application of precautionary principle was challenged in the case of Association Greenpeace France \& Others v. Ministere del' Agriculture et de la Peche \& Others, before the European Court of Justice in the year 2000. In this case, the petitioner argued that the decision has to be taken by the European Commission only on the basis of evaluation of the application in the context of safety assessment studies. ${ }^{54}$ Therefore, a complete freedom has been given to the national authorities to decide the application on the basis of precautionary rule. ${ }^{55}$ But the European Commission employed its powers to annul the authorisation, whereas the national authorities are the one who is competent to issue such orders. ${ }^{56}$ This approach seems to be in conflict with the precautionary principle because this policy provides every member state an opportunity to raise objections concerning any adverse effect on human health or the environment. ${ }^{57}$ To add to the context, the interpretation of Article 13(4) of the Council Directive 90/220 states that the national authority had to be given adequate opportunity to raise an objection concerning decision of the Commission. ${ }^{58}$

There are other instances to show that the precautionary approach is not widely accepted due to the defence available against the concept in different international instruments. For instance, the EC Biotech $\mathrm{Case}^{59}$ is a pertinent case to understand the implications of international trade of GM products and the adoption of precautionary approach in domestic legislations. The United States alleged that the de-facto moratorium imposed by the European Union for 27 GM products from the year 1999 to 2003 was found to be a trade-restrictive measure, which is contrary to the provisions formulated under the SPS Agreement. ${ }^{60}$ The United States generally does not support the precautionary principle as a rationale for food safety regulation, particularly within the international context. ${ }^{61}$ Further, in this case, the complainants contended that the precautionary approach shall be available only for a temporary period as per Article 5.7 of the SPS Agreement. ${ }^{62}$ However, the respondent, i.e., EU defended by raising an argument that the precautionary principle was considered to be a general principle of international law.

Under the circumstances, it argued that the precautionary principle has been incorporated in various international agreements such as the Cartagena Protocol on Bio-safety besides the domestic legislations of many countries. ${ }^{63}$ But the Panel did not accept these arguments, rather it delivered the opinion stating that the precautionary principle must not act as a defence for implementing trade-distortive measure concerning GM legislations. ${ }^{64}$ In citing references from Hormone Treated Beef Case ${ }^{65}$, the Panel found that the relevance of the precautionary principle is still unsettled in international law. If the precautionary approach was not given adequate recognition across international jurisprudence, it is hard to develop the liability norms to deal with damage concerning the development of GM food and derivatives. 


\section{Liability framework in different jurisdictions}

\subsection{Common law actions}

In common law jurisdiction, tort law of Europe is often used as one of the tools to deal with the issues of liability. It shall constitute an efficient mechanism to allow the victim to claim compensation against the offenders. The requests for compensation in actions for personal or property damage was based on a theory of strict liability, civil liability, negligence, trespass, and nuisance. ${ }^{66}$ Though the agricultural biotechnology comes within the sphere of trespass and nuisance, but these remedies are not applicable for the damages arising in respect of food biotechnology. ${ }^{67}$ Negligence, breach of warranty and strict liability are the ones to be considered for common cause of action concerning food liability. ${ }^{68}$ For any case of food poisoning, the victims possess the right to sue the food operators from manufacturing to retailers under common law jurisdictions like negligence or strict products liability.

The FBO should prove that he had taken 'reasonable care' to prevent the occurrence of harm. The 'reasonable care' in a sense, the food manufacturer is under obligation to maintain safe manufacturing practices to produce safe food by eliminating unreasonable dangers. This feature has motivated the great private quality control by introducing higher standards by the food industries to substantiate their 'due diligence'. This is because the risk of a liability settlement is large enough to bankrupt a company which may be greater for smaller operators. However, major retailers and manufacturers adopted the 'due diligence' and followed in their decision-making, perhaps because it is the most obvious constraint on their activities. For any case of negligence, the burden of proof lies on the victims to substantiate that the act of FBO caused food illness. But proving causation is tough in the case of damage arising out of GM food and derivatives.

The foundation of the strict liability is evolved from the case of Rylands $v$. Fletcher. ${ }^{69}$ It articulates the liability to the offender, even if the intention was not to create harm. The four components such as defendant must have brought something onto his land, non-natural use of land, and if it escapes which is likely to cause mischief and its exit leads to a dangerous substance are required to prove the causation of the claim in the doctrine of strict liability. In modern statutory law of Europe 'use' is considered to be 'non-natural', if it is an exclusive use that creates an abnormal risk of harm to another person's property. The occupier of the land is liable for damage caused by an escape and has several defenses. ${ }^{70}$ For instance, the act of a stranger, statutory authority, consent of the plaintiff, default of the plaintiff, or act of God are the defences available for the occupier of land in the case of arising damage given under tort law of Europe.

For any case of food contamination, the plaintiff must prove that the product manufactured and sold by the defendant is inherently defective and dangerous. Moreover, it needs to be proved that the results of these caused the food illness. Everyone in the food distribution chain, irrespective of food manufacturer, operator, distributors, wholesaler, and the retailer is liable for food contamination under strict liability regime. However, these common law remedies are not sufficient to deal with the potential harm of the GMO, and consumer and organic farmers are facing tremendous difficulties in gaining compensation for personal injury and damage to property. Firstly, it is debatable as to what extent tort law remedies may apply to GM contamination, as 'the GMO-related harms are not the kind of potential injuries anticipated within the principles of the torts scheme'. ${ }^{71}$ The tort law remedies are devised during the 19th century much 
before the advent of GM technology. ${ }^{72}$ It is debatable whether old tort law remedies are relevant to the uniqueness of 21 st century GMO technology.

\subsection{Development of liability framework across other jurisdictions}

The realistic thought is of the opinion that the GM foods do not pose risks, and therefore liability regime shall be derived from existing agricultural legislations; while the other line of thought considered GM food as dangerous and argued for special laws to deal with damage arising out of domestic introduction or import. The countries such as the United States, Canada, the UK and New Zealand shows a pragmatic approach and strictly believed that the liability mechanism found in existing agricultural legislations would cover the aspects of liability regime for GM foods. ${ }^{73}$ On the other hand, the European Union and Japan considered GM food as a threat because of its scientific uncertainty and therefore established a specific liability regime to deal with damage arising out of GM food and derivatives. ${ }^{74}$

\subsubsection{European Union scenario}

\subsubsection{Strict liability and fault-based liability}

The foundation of the 'strict liability' was evolved in the case of Rylands v Fletcher ${ }^{75}$ articulated the liability of the wrong-doer, even if the intention was not to create harm and the event is based on absolute duty. The European Union finally succeeded in adopting the Environmental Liability Directive, i.e., Directive 2004/35/EC in the year 2004 to establish a common framework for environmental liability for damage to air, land, water, protected species and natural resources. ${ }^{76}$ According to the Directive 2004/35/EC, the member-states of the EU are required to follow strict liability principle to deal with damages arising out of introduction or import of foods which mostly covers primary agricultural products. Food operator conducts risk or potentially risky activities scheduled under strict liability. Accordingly, in the European Union, the activities relating to GMOs including GM foods are considered as risky and fall within the purview of the strict liability doctrine. ${ }^{77}$

In addition to strict liability doctrine, the Directive 2004/35/EC provides another form of liability known as the environmental liability of food operators, it is established as a fault-based liability under the Directive. ${ }^{78}$ It is applicable in cases not covered under Annex III of the Directive when food operator causes damage to biodiversity. ${ }^{79}$ In this case, the defence was available for the food operator for which he has acted in good faith in the discharge of his duties. In such cases, the court becomes the competent authority to exempt him from such liability.

\subsubsection{Product liability}

The product liability doctrine as international standards for dealing with damage dates back to the 1980 s. $^{80}$ Product liability is an ex-post regulation that makes the company responsible for the harm caused by the manufacturing of insufficient quality. Direct regulation and product liability will complement or substitute each other in establishing incentives for businesses to engage in effective quality control. ${ }^{81}$ In the case of European Union, the product liability law was enacted in the year 1985 in the form of 
Council Directive 85/374/EEC to ensure the protection for consumers and to reduce the disparities among the national legislations. ${ }^{82}$ For determining the product liability, the injured person has to prove three elements to substantiate the case. ${ }^{83}$ At first, the product must be inherently defective, and it is unreasonably dangerous for intended use; secondly, the defect must exist in the product after transfer from source and finally the defect must have been the proximate cause of the sustained injury.

\subsubsection{BRICS countries perspective}

The contamination of GM foods is not only an issue for the countries engaged in the GM cultivation or consumption, it is even an issue in other countries, because of GM contamination. $^{84}$ The GM Contamination Register $^{85}$ provides an instances of contamination occurred to conventional crops by the GM food crops. For example, 396 incidents have been reported with contamination caused by the GM food crops across 63 countries since 1997 to $2013 .{ }^{86}$ Among these, the conventional variety of rice faced the highest amount of contamination, though there has been no commercial cultivation of GM rice anywhere in the world market. ${ }^{87}$ The BT63 rice from China and Liberty Link Rice (LLRICE) from the United States (US) shows a contamination of 35\%, while maize shows $25 \%$ contamination and soybean and rapeseed about $10 \%$ respectively. ${ }^{88}$

In February 2016, the Russia denied the import of soybean and corn from the United States because most of the crops developed are found to be GM. ${ }^{89}$ Several countries in Africa, especially South Africa have enacted specific legislations on GM food to regulate the activities relating to GMOs. ${ }^{90}$ Even though the population is reported to have faced difficulties with the scarcity of food, the regulators refused to import GM crops considering the safety surrounding such foods. ${ }^{91}$ In India, the traces of cotton seed oil developed from BT cotton which were not approved for human consumption in India have been found in market products since its inception in the year 2002. ${ }^{92}$ Accordingly, in Russia, the question of legal liability for injury caused by the GM food, right from the manufacturing phase to the human consumption emerges as a crucial issue confronting the promotion of GM food. ${ }^{93}$

In South Africa, the liability has been dealt with in the specific legislation, called Genetically Modified Organisms Act, $1997 .{ }^{94}$ Before the introduction of the above law, the ultimate responsibility to prove the causation has been on the consumer. ${ }^{95}$ Further, the liability has been determined for both the regulators and consumers under the Genetically Modified Organisms (Amendment) Act, 2006, which was primarily introduced to give effect to the Cartagena Protocol on Biosafety, which South Africa ratified in 2003. In addition to the liability provisions mentioned in the GMO Act, there are other legislations which deal with the damage caused by the GM food and derivatives. The producer, importer, distributor or a retailer was liable for any harm caused by the import or distribution of unsafe goods. ${ }^{96}$ Further, a product failure, defect or hazard in any goods, inadequate and false descriptions in the label, resulting in a loss of consumer include death, illness, loss of personal damage or to property and economic loss shall be compensated as per the Consumer Protection Act, 2008. ${ }^{97}$

In the case of Brazil, the provisions in relation to civil liability and administrative liability concerning GM food and its derivatives are incorporated in Article 20 and 21 of Law No. 11,105 of 2005 with certain exceptions. ${ }^{98}$ The regulators of Brazil opposed the strict liability doctrine and agreed to adopt a narrow definition of damage and a close 
definition of the operator. Article 20 of the Law No. 11, 105 of 2005 contemplates that the offenders were ultimately liable in the form of indemnification and reparation for any damage caused to the third party or the environment. Article 21 contemplates that any actions or omissions that violate or negate the standards established by shall be considered as administrative violations. ${ }^{99}$ Such actions shall be punished by observing precautionary measures to seize the products, suspend the sale of the products and cancellation of the registration, license or authorisation.

In China, the organisation involved in the production or processing of GM food shall be liable for any accidents. ${ }^{100}$ The organisation is liable to take immediate actions observing Article 5 of the N-KL Protocol on Liability and Redress. ${ }^{101}$ The information relating to the accident must be communicated to the Administrative Departments for further actions. Further, in the case of illegal production and the application of GMOs without due consent, a suspension shall be ordered, or the Ministry of Agriculture shall impose a fine after observing the provisions mentioned in the Regulations on Safety of Agricultural Genetically Modified Organisms. ${ }^{102}$ The provision for imposing punishment for the FBO in the case of illegal import of GM food is also available in the Regulations on Safety of Agricultural Genetically Modified Organisms. ${ }^{103}$

In the case of Indian Food Safety and Standards Act, 2006, it does not have any provisions to deal with response measures rather it provides food recall procedures in Section 28 of the Act. ${ }^{104}$ Through this provision, the FBO is entitled to initiate procedures for withdrawal of marketing food if he believes that the food he has processed, manufactured or distributed is not in compliance with this Act. ${ }^{105}$ The operators shall exercise this option only after informing the reasons for withdrawal to the designated authorities. ${ }^{106}$ In addition to this provision, Section 34 of the FSS Act, 2006 empowers the designated officers to issue an emergency prohibition notice for imposing the ban against the health risk in respect of any food business. ${ }^{107}$

The varying standards and approaches towards dealing with damage is a major bottleneck in the development and realisation of an international civil liability system for GM foods. Moreover, the BRICS countries do not have a comprehensive liability policy that applies to liability and damages arise out of domestic introduction and import of GM food and derivatives. ${ }^{108}$ Liability and redress framework has been worked out to a limited extent in South Africa and Brazil. ${ }^{109}$ But it is not well addressed in India and China. All the three countries other than Brazil already experienced with the issues of contamination of GM to that of conventional counterpart. ${ }^{110}$ Currently, South Africa is interested in relaxing its stringent legislation to regulate GMO and to promote the import of corn from the United States and Mexico. ${ }^{111}$

In the case of South Africa, the provisions relating to liability was available to both regulators and as well as the applicants, while in the case of China, the liability provisions have been fixed only for the claimants and not for regulators. ${ }^{112}$ But in India, the liability provisions are available to the regulators for dealing with the conventional food but not for GM foods. ${ }^{113}$ Further, the 37th Report of the Committee of Agriculture had also highlighted the importance of liability clause in the form of claim, compensation for any adverse effects on the health of consumers, which needs to be established to address the emerging GM food and its derivatives in India. ${ }^{114}$

After the thorough analysis on the development of liability framework in the countries of BRICS, the result is that the provisions available in the existing laws are not sufficient to deal with damage, such as the long-term effects concerning the 
manufacturing to consumption of GM food and derivatives. The domestic legislations or the machinery in these countries do not address many crucial issues the definition of damage, parties to the suit, determination of liability, proof of damage, exemption of liability, and expiration of liability concerning suit for damages. Therefore, it either requires an amendment to the existing legislation or incorporation of a specific liability law as in the case of European Union to deal with the damage in relation to production and consumption of GM food and derivatives.

\section{Development of liability framework for GM food and derivatives in India}

It is clearly evident from the 37th Report of the Committee on Agriculture submitted to Lok Sabha in the year 2012 that the implementing rules or regulations considering GM foods was not developed so far. ${ }^{115}$ Further, in the year 2013, the Committee on Agriculture was again constituted to review the governmental actions on the basis of recommendations of the 37th Report of Committee on Agriculture. ${ }^{116}$ The report of the Committee suggested that the liability mechanism for the basic import and as well as domestic introduction is not addressed. As envisaged by Article 5 of the N-KL Protocol, India must frame measures for the operators to keep informed about the damage occurring during the transboundary movement of GM foods to the designated competent authority. ${ }^{117}$ The review of liability framework exist upon other domestic legislations is discussed hereunder.

\subsection{Common law remedies}

The defect is measurable only by the adequate standards established by the legislation. However, the issue of principles of liability was taken up only after the Bhopal Gas Disaster Case ${ }^{118}$ and the Oleum Gas Leak Case ${ }^{119}$ which gave a new dimension to the tort laws in India. In the Bhopal Gas Disaster Case, the Supreme Court of India held that all kinds of liability arising out of the accident should be fixed upon to the industry and Government of India. ${ }^{120}$ The adoption of the principle of liability is the main issue of this case. ${ }^{121}$ The court has imposed the principle of absolute liability to pay damages to the harm. ${ }^{122}$ According to the principle of absolute liability, there shall be no defence available to the industry to substantiate that it had taken reasonable measures to ensure the safety of consumers. ${ }^{123}$ This principle is very much relevant to deal with a technology whose safety and risk potential is unknown. Though this principle is substantially relevant to deal with the damage arising out of introduction and import of GM foods, the principle of corporate liability is opposed by many judicial opinions.

Further in the Oleum Gas Leak Case ${ }^{124}$, the Court concluded that the rule of strict liability evolved in 1866 in Rylands v. Fletcher ${ }^{125}$ does not entirely meet out the needs of modern society with highly developed scientific knowledge and technology. ${ }^{126}$ The food operators are under obligation to engage in the activities involving hazardous substance with higher standards of safety. This makes the food operators absolutely liable for causing harm even if they conducted the business with due diligence. The Supreme Court of India introduced the new doctrine of absolute liability in the place of the existing doctrine of strict liability to deal with the harm arising with novel technologies. ${ }^{127}$ It makes sense that if the biotech industry engaged in the activity of manufacturing GM 
foods create harm to human health, then the industry is absolutely liable to compensate the victims who are affected by consumption of the product. Such liability shall not be subjected to any exceptions which operate vis-à-vis the tortuous principle of strict liability under the rule of England courts in the case of Rylands Vs Fletcher. ${ }^{128}$

In the case of criminal liability, the seller, and manufacturer both are liable for their defective product that is not in compliance with the standards prescribed by the legislation. ${ }^{129}$ Moreover, they are said to be responsible for their criminal intention to sell the defective products which cause personal injury or death of a consumer due to the availability of adequate amount of toxicity in the product. Apart from the Indian constitutional mandate, there are plenty of legislations on the subject, but more relevant enactments are the Environmental (Protection) Act, 1986 (hereinafter 'EPA, 1986'); Consumer Protection Act, 1986 (hereinafter 'CPA, 1986'); and Food Safety and Standards Act, 2006 (hereinafter 'FSS Act, 2006').

\subsection{The constitutional mandate}

The standards of liability shall be consistent with that of constitutional provisions and also in the present day economy and social structure. By observing the constitutional provisions, the State is liable to improve standards to protect public health as per the mandate of Articles 39, 41, 42 and 47 of the Directive Principles of State Policy. ${ }^{130}$ According to Article 47 of the Indian Constitution, the State is empowered to raise the standard of living to improve public health and to prohibit the consumption of unsafe food which is injurious to human health. ${ }^{131}$ Moreover, the right to life under Article 21 shall be broadly interpreted to include the concept of the right to health. The contamination of foods was considered to be a gross violation of the right to life that is enshrined in the Article 21 of the Indian Constitution. If the industries are established without obtaining the requisite permission and clearances and if the industry continued to be run in blatant disregard of citizens living in the vicinity, the Court has the power to intervene and protect the fundamental right to life and liberty of the citizens of the country.

Though the comprehensive action is being taken after the establishment of the Food Safety and Standards Authority of India (FSSAI), the sale of adulterated and synthetic milk is highly common in most parts of India. For instance, the survey report of the FSSAI titled 'Executive Summary on National Survey on Milk Adulteration, 2011' concluded that $68.4 \%$ of the milk being sold in the national market is adulterated. ${ }^{132}$ Reacting to this, a petition was filed in the form of Public Interest Litigation before the Supreme Court of India in the Swami Achyutanand Tirth and Others v. Union of India and Others. ${ }^{133}$ The pleadings of the petitioner was that the FSSAI's inaction in discharging its regulatory functions to inspect and rule out sale and distribution of synthetic milk and milk products across the country was a clear violation of the fundamental rights guaranteed under Article 21 of the Indian Constitution.

\subsection{The Environment (Protection) Act, 1986}

The manufacturing of GM food and derivatives shall be presumed to cause a long-term health effect on human beings. As per the decisions made at the United Nations Conference on Human Environment, 1972, ${ }^{134}$ India has enacted the Environment 
(Protection) Act in the year 1986 with an objective to protect and improve the quality of the human environment and to prevent, controlling and abating environmental pollution. ${ }^{135}$ Therefore, the contaminations found in the vegetables cultivated, and food imported and distributed must be addressed with a proper redress system as per the environmental legislations. According to Section 2(f) of the EPA, 1986, the term 'occupier' includes the person who is responsible for controlling the affairs of the industry. ${ }^{136}$ Further, the environmental liability must be imposed retroactively with strict liability for redress as per the mandate of the EPA, 1986. ${ }^{137}$ Therefore, the principle of strict liability is exercised while dealing with the cases relating to damage to the environment. Section 15 of the EPA, 1986, laid down the penalty for violations of the provisions of this Act. ${ }^{138}$

\subsection{The Consumer Protection Act, 1986}

The product liability claims is not found elsewhere in any of the Indian Statute and shall be said to have emerged from different legislations such as Consumer Protection Act, $1986^{139}$ and Food Safety and Standards Act, 2006. Section 2(31) of the proposed Consumer Protection Bill, 2015 (CP Bill, 2015) defined the term 'product liability' as follows:

\footnotetext{
“"product liability' means the responsibility of a manufacturer or vendor of goods or service provider to compensate for injury or damage caused to a consumer by defective product sold to a consumer or deficiency in services"
}

If the product or derivative thereof creates any harm to the consumers, then the manufacturer is held liable for damage under the proposed CP Bill, 2015. It means that the producer is liable for any defects in the finished product or of a component of the finished product. In such case, the consumer who had suffered from injuries shall make a claim for compensation by invoking the provisions of Consumer Protection Act, 1986. Here, the 'complainant' shall be a 'consumer', and the definitional clause is found in Section 2(b) of the CPA, 1986. ${ }^{140}$ As per Section 2(d) of the Consumer Protection Act,1986, the consumer means a person who buys any goods for consideration.

It further defines the term 'defect' in Section 2(f) of the Consumer Protection Act, 1986 which means any fault, imperfection or shortcoming in the quality, quantity, potency, purity or standard that is to be maintained in agreement with law. ${ }^{141}$ It is assumed that, if any manufacturer involved in the manufacturing of GM foods is found guilty, then he shall be prosecuted under the Consumer Protection Act, 1986. ${ }^{142}$ The Consumer Protection Act, 1986 is applicable in the case of damage caused at the stages of domestic production and as well as import of goods. It introduces statutory liability for defective products and imposes a strict liability for the manufacturers without any exemptions. ${ }^{143}$ To prove the strict liability, the consumer need not substantiate that the manufacturer is negligent in performing its duties, rather it is enough to show that the product is defective. Therefore, the liability as mentioned in the Consumer Protection Act, 1986 is joint, and several and the injured party is entitled to sue any of the persons involved from the manufacturing level to the retail distributors. It is an assumption that, in the case of GM food and derivatives, the manufacturer of the final product and the manufacturer of the derivative part is potentially liable for any damage arising with respect to consumer health. Moreover, the Consumer Protection Act, 1986 does not 
prevent the consumer from going to a civil court for compensation for the loss or damage caused to them.

Therefore, the consumer may initiate proceedings invoking provisions from existing legislations depending on the circumstances. ${ }^{144}$ For instance, the false claims concerning the promotion of sale are considered to be an 'unfair trade practice' is as defined in Section 2(1) (r) of the Consumer Protection Act, 1986. Similarly, Section 24 of the Food Safety and Standards Act, 2006 (FSS Act, 2006) contemplates that those who makes false claims concerning the nutritional value of the product without providing any scientific justification is considered to be the gross violation of the Act. ${ }^{145}$ Therefore, manufacturers, dealers, and importers of food items are required to comply with the provisions while advertising or disseminating information to the public. Recently, the Parliamentary Committee on Food, Consumer Affairs, and Public Distribution favoured stringent laws to deal with misleading advertisements and fixing liability for celebrities. $^{146}$

To widen the ambit of the scope and to modernise the Consumer Protection Act 1986, the Consumer Protection Bill was introduced in the Lok Sabha in the year 2015. Sections 72 to 75 of the newly introduced 'Consumer Protection Bill, 2015' (hereinafter 'CP Bill, 2015') added the provisions related to product liability. ${ }^{147}$ According to Section 72 of the CP Bill, 2015, the manufacturer, producer of a product is liable for personal injury, death, or property damage resulting from the defects in the manufacture, marketing, packaging, labelling of the product. For the claim relating to product liability, the claimant has to prove that the product contains manufacturing defect and there is a deviation in manufacturing specifications; the defendant was the manufacturer of the defective product, and the dangerous aspect of the product was the proximate cause of the harm suffered by the claimant. ${ }^{148}$

\subsection{The Food Safety And Standards Act, 2006}

GM food is considered as non-standardised foods and requires product approval procedures as per Section 22 of the FSS Act, 2006 which laid down the foundation for product liability. ${ }^{149}$ But there is no specific provision in the FSS Act, 2006 to determine product liability. Though the product liability has been considerably addressed in the CP Bill, 2015, the development of essential components of product liability system ${ }^{150}$ such as definition of damage, channelling of liability, nature of claims, proof of damage, exemption from liability and expiration of liability must be analysed.

\subsubsection{Definition of damage}

Generally, damage is caused as a result of the defect in a product and it is essential to define it before discussing the scope of damage. As per Article 9 of the Council Directive $85 / 374 / \mathrm{EEC}$, the term 'damage' referred to death or personal injuries or destruction of property. ${ }^{151}$ It is unfortunate to note that there is no precise definition of 'damage' in the FSS Act, 2006. Moreover, the evaluation of damages is an important phenomenon for the determination of compensation for injuries. Here, the safety assessment plays a crucial role in providing the essential information about the nature of GM food and derivatives. The scope of damages is also not addressed in any of the provisions in the FSS Act, 2006. 


\subsubsection{Channelling of liability and determination of liability}

Channelling of liability is very much necessary because the final food product contains various ingredients manufactured and transported from different countries that have the possibility of causing harm to human health. For example, it is reported that in a simple dish like pizza, 30 ingredients from 66 countries are being used. ${ }^{152}$ The damages are possible at any stage of food production. If any injury occurs to the consumer health, then the question arises to whom the liability shall be fixed. So, primarily, a food manufacturer is liable for any damage caused by a defect in a product. Section 3(1)(o) of the FSS Act, 2006 defines the term 'FBO' as:

"in relation to food business means a person by whom the business is carried on or owned and is responsible for ensuring the compliance of this Act, rules and regulations made thereunder."

According to this definition, a FBO means a person involved in the process of carrying out the activities such as manufacture, processing, packaging, storage, transportation, distribution and import. ${ }^{153}$ The proper conduct of the food business must be in compliance with the standards and regulations prescribed by the FSS Act, 2006. As per Section 27 of the FSS Act, 2006, ${ }^{154}$ the liability has been fixed only for the manufacturers, packers, wholesalers, distributors and sellers and not to exporting and importing country. The development of liability mechanism is very much essential for the exporting state and the importing state to deal with the damage occurring during the transboundary trade. It is unfortunate to note that the liability mechanism under the FSS Act, 2006 is available only for the damage happened during authorised release. The requirements relating to the mechanism of liability for unauthorised release of GM food and derivative also need to be developed.

It may also be noted that there is a shared responsibility between the industries and the government in managing liability concerning GM food and derivatives. As stated earlier, the regulatory actions of the government will likely to compensate the absence of an elaborative definition of FBO. As envisaged in Section 25(1) of the FSS Act, 2006, the Central Government is empowered to prohibit or restrict the import of unsafe food by the Foreign Trade (Development and Regulation) Act, 1992. Therefore, the import of food with no scientific studies of safety will be restricted at the port of entry into India.

\subsubsection{Nature of claims}

The violation of obligations of the FBO or the infringement of the rights of consumer decides the nature of the claim. The requirements of the FBO in the context of the manufacturing of GM foods shall be understood by the interpretation of Section 26 of the FSS Act, 2006. ${ }^{155}$ It shall be construed in two sequences. First of all, the responsibility of the FBO to ensure that the products at every stage of its development such as production, processing, import, distribution and sale must be in compliance with the standards prescribed by the Act. Secondly, the FBO is not entitled to manufacture, store, sell or distribute any products which are found unsafe, misbranded or sub-standard or contains extraneous matter, without obtaining a license from the authorities established by Government. Therefore, the FBO is liable for any contraventions of the provisions of the FSS Act, 2006 and its accompanying regulations. In such case, the victims shall raise a claim against the FBO for damage. 
The legal basis for claiming liability for GM foods shall be in the form of liability for contract, liability in tort and the administrative liability. In the case of responsibility of contract, the rights and obligations will be set in the contractual agreement between the manufacturer of the exporting state and the processing industry. For instance, the manufacturing sector is in the United States and the food processing industry in India, and if any contradictions arose in respect of contractual relationship, then the aggrieved party shall file a suit for the recovery of breach of contract. For any damage in the form of injury or death by the consumption of imported or domestically produced GM food and derivatives, the victims shall file a suit for recovery of damages against the manufacturer or seller of the product. For a liability in tort, the civil action shall be filed by the aggrieved party against the FBO. For the administrative responsibility, the authorities established under the FSS Act, 2006 is entitled to protect the consumers from the harm caused by the consumption of unsafe food manufactured and transported by the FBO. However, the customer entitled to a remedy under the Consumer Protection Act, 1986. In addition to this, the state agencies are responsible for the violation of norms and damage caused to the consumer.

\subsubsection{Proof of damage}

The aggrieved person or the injured is under obligation to prove the cause of the claim. In this regard, the plaintiff has to keep three elements in mind to prove his assertion, i.e., sustained injury or damage, product is defective and the damage caused was the resultant of the defect in the product. In the case of strict liability, a plaintiff needs to prove only two things. First of all, he has to show that the product is inherently defective. The plaintiff has to prove that the defect in item had arisen after the export of goods from the state of export. The fault shall be detected by sending the product to the accredited laboratories for the test. Secondly, the injury or damage should be the result of the defect in the product. In this case, the plaintiff has to establish the causal connection between the inherent defect and the injury for the claim of damage. The analysis on the current FSS Act, 2006 revealed that there is no provision to describe the essential requirements for the claim of the plaintiff to substantiate his case of a claim in a suit relating to GM food and derivatives. Therefore, the requirements for the plaintiff to prove his claim need to be developed in the FSS Act, 2006.

\subsubsection{Exemption from liability}

The general tort law showed that the burden of proof should be laid on the plaintiff, whereas in certain circumstances, the industry has the burden to prove its eligibility to claim exemptions. The product recall procedure will be an appropriate option available to the manufacturers to save them from the payment of compensation. Section 28 of the FSS $\mathrm{Act}^{156}$ is the specific provision that deals with the product recall procedure. Through this provision, the FBO is entitled to initiate procedures for withdrawal of marketing food if he believes that the food he has processed, manufactured or distributed is not in compliance with this Act.

The FBOs are entitled to exercise this option only after informing the reasons for withdrawal to consumers. In M/s. Nestle India Limited VS The FSSAI and Others ${ }^{157}$, the manufacturer immediately applied a product recall option to save from further liabilities. To this end, it quickly made a publication in a newspaper to provide information to the 
consumers. The standard defence that the manufacturer shall exercise is that the product intended for sale has undergone every standards and procedure established by law. But if the product is stolen or in the experimental stage, then the manufacturer is not liable to provide any damages to the victims. However, in the case of GM food, the impact will be known after a long gap, many be many months or years, which makes it difficult for the consumers to prove the case immediately. It is feared that by use of the current exemption, food business industry might escape liability by exercising the clause of exemption.

\subsubsection{Expiration of liability}

The statutory period of limitation for filing a suit for an injury commenced with the date of which the victim became aware of the damage, defect and the identity of the producer. The statutory limitation period for filing a suit for recovery of injury for the accident arose in respect of introduction or import of GM food and derivatives in European Union is 30 years. According to Section 77 of the FSS Act, 2006, ${ }^{158}$ the time limit for prosecution of a case is one year from the date of commission of the offense. But in China, the statutes of limitation for an action for the compensation for damages caused by defective products is two years, i.e., the time when the consumer found that his right is infringed. However, the right of claiming compensation for damage caused by GM food products is unattainable because of scientific uncertainty and unexpected long-term effects. $^{159}$

\section{Enforcement machinery under the FSS Act, 2006}

\subsection{Designated officers}

The designated officers ${ }^{160}$ appointed by the Commissioner of Food Safety under Section 36 of the FSS Act, 2006 is liable to serve a notice in the form of an improvement notice to the FBO for the non-compliance of standards prescribed in the regulations. ${ }^{161}$ The improvement notice will act as a warning to the FBO indulged in the activity involving GM foods to comply with the regulations for which they failed to do so. If the FBO fails to comply with the notice, then the designated officer is empowered to cancel license after providing an opportunity of being heard. In certain circumstances, the designated officer shall exercise his discretionary powers to revoke the license in the interest of the general public. In such case, the reasons for cancellation of license must be specified in writing. The FBO is entitled to file an appeal against the order of the designated officer to the Commissioner of Food Safety. There shall be a 15 days period from the date of notice of service to the FBO.

In addition to this, the designated officer is empowered to issue an emergency prohibition notice if he thinks that the food business caused a severe health risk to the consumers. He shall refer the same to the Commissioner of Food Safety to impose a prohibition on the food business. ${ }^{162}$ If the Commissioner of Food Safety is satisfied, he shall impose a ban on the food business by preparing an order. After passing of the order, the designated officer shall serve a copy to the FBO through the food safety officer. If the FBO knowingly contravenes the order, then he shall be punishable with an imprisonment of two years or a maximum fine of rupees 2 lakhs. If the FBO have taken appropriate 
measures to justify the lifting of order, then in such case, the designated officer will issue a certificate of compliance for seven days to invalidate the emergency prohibition order.

\subsection{Food safety officers}

Section 39 of the FSS Act, 2006, ${ }^{163}$ provides a measure for the industries to safeguard themselves from the arbitrary behaviour of the government official. It contemplates that in case, the food safety officer abuses his powers to seize any articles of food or adulterant, vexatiously, or any of his act causes any injury to the FBO, he shall be guilty of an offense and shall be penalised to pay a maximum fine of rupees 1 lakh. On the contrary, if the FBO makes any false complaint against the food safety officer, then the FBO is liable to pay a maximum fine of rupees 1 lakh.

\subsection{Courts and tribunals}

It is significant to note that, as things stand today, whether the courts will recognise a duty of care in any particular case depends on the foreseeability of the harm and the proximity of the relationship between the parties. Damage from a cause which may be considered outside the reasonable knowledge or skill of a GM farmer may not be compensated: the courts will look at the common practice of industry to determine whether a defendant was negligent. ${ }^{164}$ The specific standards of each legal issue are also required to reflect the precautionary principle.

In case the product involves serious risk to consumers, the court is empowered to issue prohibition orders through the food safety officers to the FBO after giving an opportunity of being heard. ${ }^{165}$ In case, the FBO continues to contravene the orders of the Court then he shall be guilty of an offense and be punishable for a maximum penalty of rupees 3 lakhs. If the FBO complied with the orders by establishing suitable measures to justify the lifting of the prohibition order, then the concerned food safety officer with the approval of designated officer shall issue a Certificate of Compliance within seven days based on the application of the FBO. A six-month statutory period of limitation shall be given to the FBO to revoke the prohibition order issued by the Court.

Though the aggrieved FBOs are entitled to file an appeal under Section 46(4) of the FSS Act, 2006, there exists an availability of alternative remedy under Article 226 of the Indian Constitution in the form of writ jurisdiction before the concerned High Court. If any orders of the food authority were in gross violation of legal rights or natural justice, then the aggrieved party is entitled to approach an alternative forum under the Writ Jurisdiction of High Court for the violation of any fundamental rights or other rights. For instance, in M/s. Nestle India Limited v. The FSSAI and Others ${ }^{166}$, the Writ Petition has been filed against the FSSAI before the High Court of Bombay for violation of Articles 14 and 21 of the Indian Constitution. ${ }^{167}$

\section{Conclusions}

India has already included certain key provisions of liability in the FSS Act, 2006. However, much of its attention has been about non-compliance with the procedural requirements of the legislation rather than issues concerning food safety as such. It may 
be noted that the determination of risk is a pre-requisite for the establishment of liability provisions concerning emerging GM food in India. In the case of technologies whose potential for risk and safety for consumption has not been scientifically established, preventive measures require the adoption of stringent liability regimes. The same goes for modern biotechnology by the precautionary principle which provides the legal basis for addressing the uncertainties linked to this novel technology. If the country wants to promote industries as in the case of nuclear industries, then the provision of liability should be suitably formulated.

The national legal framework addressing the liability over GM foods is not adequately established in the current FSS Act, 2006. Concerning this, the key components of liability law such as definition and scope of the damage, determination of liability, nature of claims, standards of liability, proof of harm, exemption from liability and expiration of liability must be included in the legislation to strengthen the liability mechanism. Moreover, the channelling of liability is an important aspect that should be considered while determining liability for damage arising out of GMOs including GM food and derivatives. It is submitted that both industry and government plays a decisive role in the determination and management of liability in relation to GM food and derivatives. Accordingly, it is suggested that appropriate directions needs to be given to the industry to follow the Stewardship Program to ensure the safety at all levels right from research and development to commercialisation of the products.

Further, the right of claiming compensation for damage caused by GM food products may be unrealisable in view of the scientific uncertainty and unexpected long-term effects. Hence, the time limitation as envisaged in Section 77 of the Food Safety and Standards Act, 2006 for prosecution of a case should be revised as in the case of EU (30 years). Even though the N-KL Protocol has not specifically attempted to define the criteria, it is desirable for the country to include the provisions in the current legislation to deal with the damages because of recent decision in importing GM food in the form of additives. Under the circumstances, the adoption of GM food without adequate development of liability norms will be a major concern for the developing countries like India where there are several threats of contamination.

Therefore a considerable attention is required to determine the procedures of legal liability to deal with the damage which occurs at all stages of GM food production to human consumption. Moreover, the Indian lawmakers must take into account the development of liability mechanism concerning the import or domestic introduction of GM foods either through an amendment to the existing FSS Act, 2006, or through a dedicated GM food liability law. A focussed liability rules, both at the international and domestic levels, will save us from the unnecessary and unwarranted litigation surrounding the GM liability. If India is attempting to adopt an appropriate liability policy with an ideal of international standards, the future risk of the GM products will be avoided to a greater extent. 


\section{Notes}

1 Liener, I.E. (1994) 'Implications of anti-nutritional components in soybean foods', Crit. Rev. Food sci. Nutr., Vol. 34, No. 1, pp.31-67.

2 Losey, J.E. et al. (1990) 'Transgenic pollen harms monarch larvae', Nature, Vol. 399, No. 6733, p.214.

3 Ewen, S. and Pusztai, A. (1999) 'Effect of diets containing genetically modified potatoes expressing Galanthusnivalislectin on rat small intestine', The Lancet, Vol. 354, No. 9187, pp.1353-1354.

4 Duall, E. (2004) 'A liability and redress regime for genetically modified organisms under the Cartagena Protocol', Geo. Wash. L. Rev., Vol. 36, No. 1, pp.173-201.

5 World News Daily Report, 'Doctors confirm first human death officially caused by GMOs [online] https://worldnewsdailyreport.com/doctors-confirm-first-human-death-officiallycaused-by-gmos/ (accessed 20 December 2016).

6 In January 2015, the Doctors of Carlos III Hospital announced that the 31 year old, Spanish man, Mr. Juan Pedro Ramos died from anaphylaxis after consuming the tomatoes contain genes of fish and other antibiotic resistant genes which caused the allergic reaction that caused the death. After hearing this news, the Ministry of Health, Social Services and Equality ordered for the recall and removal of tomatoes of Portuguese origin for safety reasons. Doctors Confirm First Human Death Officially Caused by GMOs [online] http://worldnewsdailyreport.com/doctors-confirm-first-human-death-officially-caused-bygmos/ (accessed 24 March 2015).

7 Nordlee, J. et al. (1996) 'Identification of a Brazil-nut allergen in transgenic soybeans', The New England Journal of Medicine, Vol. 334, No. 11, pp.688-692.

8 IFOAM EU Group, Preventing GMO Contamination: An Overview of National 'Coexistence' Measures in the EU [online] https://www.ifoam-eu.org/sites/default/files/ifoameu_policy_ gmos_dossier_201412.pdf (accessed 21 December 2016).

9 Price, B. and Cotter, J. (2014) 'The GM contamination register: a review of recorded contamination incidents associated with genetically modified organisms (GMOs), 1997-2013', Int'l. J. of Food Contamination, Vol. 1, No. 5, pp.1-13.

10 WASC 187 (2014).

11 Organic Farmer Steve Marsh Loses Bid for High Court Review of Genetic Modification Contamination Case [online] https://www.abc.net.au/news/2016-02-12/gm-contaminationfarmer-loses-bid-for-high-court-review/7163506 (accessed 21 December 2016).

12 In re Star link Corn Products Liability Litigation, Marvin Kramer, et al. v. Aventis Crop Science USA Holding, Inc., et al. 211 F. Supp. 2d 1060 (N.D. Ill. 2002).

13 The Case is in Lis-pendens, Case No. 3:15-cv-03952-HSG (filed 28 August 2015).

14 Gallagher v. Chipotle Mexican Grill Inc., No. $15-03952$ (2015). The case is in lis-pendens.

15 Duall, E. (2004) 'A liability and redress regime for genetically modified organisms under the Cartagena Protocol', Geo. Wash. Int'l. L. Rev., Vol. 36, No. 1, pp.173-201; Koch, B. (2007) 'Liability and compensation schemes for damage resulting from the presence of genetically modified organisms in non-GM crops', Eur. Centre of Tort \& Ins. L. J.

16 Smyth, S. et al. (2006) 'Managing liabilities arising from agricultural biotechnology', Regulating Agricultural Biotechnology: Economics and Policy, pp.81-101, Springer; see also, Balashanmugam, S.K. et al. (2015) 'Liability aspects related to genetically modified food under the food safety legislation in India', Int'l J. of Soc., Behav., Educnl., Econ, Bus and Ind. Engineering, Vol. 9, No. 12, pp.4060-4065.

17 Philips, P. and Corkindale, D. (2002) 'Marketing GM foods: the way forward', AgBioForum, Vol. 5, No. 3, Article 6, pp.113-121.

18 Hagen, P. and Weiner, J.B. (2000) 'The Cartagena Protocol on Biosafety: new rules for international trade in living modified organisms', The Georgetown Int'l Envtl. Law Review, Vol. 12, No. 3, pp.697-717. 
19 Maghari, B.M. and Ardekani, A.M. (2011) 'Genetically modified foods and social concerns', Avicenna Journal of Medical Biotechnology, Vol. 3, No. 3, pp.109-117.

20 Lev, T.L. (2017) 'Liability for environmental damages from the offshore petroleum industry: strict liability justifications and the judgment-proof problem', Ecology Law Quarterly, Vol. 43, No. 2, pp.483-494.

21 Article 4, Strict Liability, Basel Convention on the Control of Transboundary Movements of Hazardous Wastes and their Disposal, 27 May 2014.

22 Article 6, Basel Convention on the Control of Transboundary Movements of Hazardous Wastes and their Disposal, 27 May 2014.

23 Article 22(1), Cartagena Protocol on Biosafety to the Convention on Biological Diversity, 11 September 2003.

24 Kramkowska, et al. (2013) 'Benefits and risks associated with genetically modified food products', Ann. Agric. Environ. Med., Vol. 20, No. 3, pp.413-419.

25 See Subramanian, S.R. (2012) 'Too similar or too different: state of necessity as a defence under customary international law and the bilateral investment treaty and their relationship', Manchester Journal of International Economic Law, Vol. 9, No. 1, pp.62-91.

26 Draft articles on Responsibility of States for Internationally Wrongful Acts, 2001 were adopted at the 53rd session by the International Law Commission in the year 2001. Final version consists of 59 draft articles which were divided into four parts. Part one deals with the Internationally Wrongful Act of the State (Articles 1-27), Part two consists of the Content of the International Responsibility of a State (Articles 28-41), the Implementation of the International Responsibility of a State (Articles 42-54) represented in Part three and Final Five General Provisions of the Text is contained in Part four (Articles 55-59); also see, Singh, C. (2008) 'The International Law Commission and state responsibility: application of a comparative paradigm on oil and watercourses', Forum on Pub Pol'y; also, see Crawford, J., Articles on Responsibility of States for Internationally Wrongful Acts, United Nations Audiovisual Library of International Law [online] http://legal.un.org/avl/pdf/ha/rsiwa/ rsiwa_e.pdf (accessed 7 October 2016).

27 Article 2 of the draft articles on Responsibility of States for Internationally Wrongful Acts, with Commentaries - Elements of an Internationally Wrongful Act of a State, there is an internationally wrongful act of a State when conduct consisting of an action or omission:

a is attributable to the State under international law

b constitutes a breach of an international obligation of the State (2001).

28 Paarlberg, R. (2014) 'A dubious success: the NGO campaign against GMOs', GM Crops \& Food, Vol. 5, No. 3, pp.223-228; also see, Hagen, P. and Weiner, J.B. (2000) 'The Cartagena Protocol on Biosafety: new rules for international trade in living modified organisms', The Geo. Int'l. Envtl. L. Rev., Vol. 12, No. 3, pp.697-717.

29 Balashanmugam, S.K., Subramanian, S.R. and Padmavati, M. (2016) 'South Asian perspective on institutional mechanism or introduction and import of GM crops', Biotechnology Law Report, Vol. 35, No. 2, pp.73-79.

30 Article 27 of the Cartagena Protocol on Biosafety to the Convention on Biological Diversity (2000).

31 Balashanmugam, S.K., Machikanti, P. and Subramanian, S.R. (2015) 'Liability aspects related to genetically modified food under the food safety legislation in India', International Journal of Social, Behavioral, Educational, Economic, Business and Industrial Engineering, Vol. 9, No. 12, pp.4082-4087.

32 Nagoya-Kuala Lumpur Supplementary Protocol on Liability and Redress to the Cartagena Protocol on Biosafety, United Nations Environment Program, Secretariat of the Convention on Biological Diversity, Montreal, Canada (2011). As of November 2016, 36 member countries have deposited the instrument for acceptance, accession and ratification which requires four more countries to enter into force. Parties to the Protocol and Signature and Ratification of the Supplementary Protocol [online] https://bch.cbd.int/protocol/parties/\#tab=1 (accessed 8 December 2016). 
33 Xiang, W. (2012) 'International liability and redress for genetically modified organisms and challenge for China's biosafety regulation', International Environmental Law: Contemporary Concerns and Challenges, pp.581-600.

34 Article 5 and Article 12 of the Cartagena Protocol on Biosafety to the Convention on Biological Diversity (2000).

35 Article 5, Paragraph 1(c) of the Nagoya-Kuala Lumpur Supplementary Protocol on Liability and Redress to the Cartagena Protocol on Biosafety.

36 Nijar, G.S. (2012) 'The Nagoya-Kuala Lumpur supplementary protocol on liability and redress to the Cartagena Protocol on Biosafety: an analysis and implementation challenges', Int. Environ. Agreements, Vol. 13, No. 3, pp.271-290.

37 Article 5, Paragraph 3 of the Nagoya-Kuala Lumpur Supplementary Protocol on Liability and Redress to the Cartagena Protocol on Biosafety.

38 Schwabach, A. (2011) 'Transboundary environmental harm and state responsibility: customary international law', International Law and Institutions (Sample Chapters).

39 Article 12, Paragraph 1(b) of the Nagoya-Kuala Lumpur Supplementary Protocol on Liability and Redress to the Cartagena Protocol on Biosafety.

40 Kohm, K.E. (2009) 'Shortcomings of the Cartagena Protocol: resolving the liability loophole at an international level', UCLA Journal of Environmental Law and Policy, Vol. 27, No. 1, pp.146-179.

41 Article 12, Paragraph 2 of the Nagoya-Kuala Lumpur Supplementary Protocol on Liability and Redress to the Cartagena Protocol on Biosafety.

42 Santoso, W.Y. (2016) 'Bridging the implementation of the Nagoya-Kuala Lumpur supplementary protocol on liability and redress in Indonesia', Indonesia Law Review, Vol. 6, No. 1, pp.58-78.

43 Balashanmugam, S.K. et al. (2015) 'Liability aspects related to genetically modified food under the food safety legislation in India', Int'l. J. of Soc., Behav., Educnl., Econ, Bus and Ind. Engineering, Vol. 9, No. 12, pp.4060-4065.

44 Balashanmugam, S.K. (2018) 'Safety assessment and liability regulations in the context of genetically modified food in the BRICS countries', BRICS Law Journal, Vol. 5, No. 1, pp.27-55.

45 Article 12, Paragraph 2 of the Nagoya-Kuala Lumpur Supplementary Protocol on Liability and Redress to the Cartagena Protocol on Biosafety

46 Koutouki, K. and Rogalla, K. (2012) 'The Nagoya protocol: sustainable access and benefits-sharing for indigenous and local communities', Vermont Journal of Environmental Law, Vol. 13, pp.513-535.

47 See, Procedure for Living Modified Organisms intended for Direct Use as Food or Feed, or for Processing, Article 11 of the Cartagena Protocol on Biosafety.

48 Tung, L. (2014) 'Transboundary movements of genetically modified organisms and the Cartagena Protocol: key issues and concerns', Potchefstroom Electronic Law Journal, Vol. 17, No. 5, pp.1740-1787.

49 Telesetsky, A. (2011) 'Introductory note to the Nagoya-Kuala Lumpur supplementary protocol on liability and redress', International Legal Materials, Vol. 50, No. 1, pp.105-113; Xiang, W. (2012) 'International liability and redress for genetically modified organisms and challenge for China's biosafety regulation', International Environmental Law: Contemporary Concerns and Challenges, pp.581-600.

50 Nagoya-Kuala Lumpur Supplementary Protocol on Liability and Redress to the Cartagena Protocol on Biosafety.

51 'Freestone, D. and Hey, E. (1996) 'Origins and development of the precautionary principle', in Freestone, D. and Hey, E. (Eds.): The Precautionary Principle and International Law, Kluwer Law International, London. 
52 United Nations Environment Programme (1992) Rio Declaration on Environment and Development, 3-14 June, Rio de Janeiro.

53 Orellana, M.A. (2009) 'Evolving WTO law concerning health, safety and environmental measures', Trade, Law and Development, Vol. 1, No. 1, pp.103-144.

54 Case C-6/99 (2000).

55 Article 5.7 of the Agreement on the Sanitary and Phytosanitary Measures, World Trade Organisation.

56 Fache, E. and Pauwels, S. (2016) Fisheries in the Pacific: The Challenges of Governance and Sustainability, Pacific-Credo Publications, France [online] https://halshs.archivesouvertes.fr/halshs-01735395/file/2016_Fisheries_in_the_Pacific.pdf (accessed 18 November 2016).

57 European Community - Measures Affecting the Approval and Marketing of Biotech Products, Reports of the Panel, WT/DS 291/R, WT/DS 292/R and WT/DS 293/R (2006).

58 Article 13(4) of Council Directive 90/220/EC on the deliberate release into the environment of Genetically Modified Organisms, Official Journal of the European Communities (1990). Where the Commission has taken a favourable decision, the competent authority that received the original notification shall give consent in writing to the notification so that the product may be placed on the market and shall inform the other member states and the Commission thereof.

59 European Community - Measures Affecting the Approval and Marketing of Biotech Products, Reports of the Panel, WT/DS 291/R, WT/DS 292/R and WT/DS 293/R (2006).

60 Articles 5.1 and 5.7 of the Agreement on the Application of Sanitary and Phytosanitary Measures, World Trade Organisation.

61 Helson, S. and Caswell, J. (1999) 'Food safety regulation: an overview of contemporary issues', Food Policy, Vol. 24, pp.589-603.

62 Article 5.7 - Assessment of Risk and Determination of the Appropriate Level of Sanitary or Phytosanitary Protection - In case where relevant scientific evidence is insufficient, a Member may provisionally adopt sanitary or phytosanitary measures on the basis of available pertinent information, including that from the relevant international organisations as well as from sanitary or phytosanitary measures applied by other members. In such circumstances, Members shall seek to obtain the additional information necessary for a more objective assessment of risk and review the sanitary or phytosanitary measure accordingly within a reasonable period of time.

63 Mackenzie, R. (2000) 'The Cartagena Protocol on Biosafety', Journal of International Economic Law, Vol. 3, No. 3, pp.525-543. The precautionary principle has its earlier reference from Preamble, followed in Article 1, 10.6, 11.8 and Annexure III of the Biosafety Protocol.

64 Para. 7.89, p.340 of Panel's Report in European Community - Measures Affecting the Approval and Marketing of Biotech Products WT/DS291/R, WT/DS292/R and WT/DS293/R adopted on 21 November 2006.

65 European Communities - Measures Concerning Meat and Meat Products (Hormones), US-WT/DS26/19 (18 May 1999) and Canada - WT/DS48/17(20 May 1999).

66 Posner, R. (2013) 'Instrumental and non instrumental theories of tort law', Ind. L. J., Vol. 88, No. 2, pp.469-525.

67 Balashanmugam, S.K. (2018) 'Safety assessment and liability regulations in the context of genetically modified food in the BRICS countries', BRICS Law Journal, Vol. 5, No. 1, pp.27-55.

68 DeConti, E.A. (2013) 'Food and beverage litigation survey', The Hospitality Law Conference, Houston, Texas, 11-13 February [online] http://hospitalitylawyer.com/wp-content/uploads/ Food-and-Beverage-Liability-Update-Summary-Case3.pdf (accessed 18 December 2016).

69 House of Lords, L.R. 3 H.L. 330 (1868) It is the landmark case to establish a new era of tort law in the United Kingdom in the year 1868. 
70 Bussani, M. (2017) 'Tort law in the European Union', The American Journal of Comparative Law, Vol. 64, No. 4, pp.1019-1023.

71 Havemann, P. (2003) 'Genetic modification, ecological good governance and the law: New Zealand in the age of risk', James Cook U. L. Rev., Vol. 10, No. 7, pp.50-72.

72 Geistfeld, M. (2014) 'Tort law in the age of statutes', Iowa L. Rev., Vol. 99, No. 3, pp.957-1020.

73 Boadi, R.Y. (2007) 'Managing liability associated with genetically modified crops', Handbook of Best Practices, Chapter 14.5, pp.1385-1392, Oxford, UK.

74 Wager, R. and McHughen, A. (2010) 'Zero sense in European approach to GM', EMBO Rep., Vol. 11, No. 4, pp.258-262.

75 House of Lords, L.R. 3 H.L. 330 (1868) It is the landmark case to establish a new era of tort law in the United Kingdom in the year 1868.

76 Pouikli, K.C. (2016) 'Overview of the implementation of the Directive 2004/35/EC on environmental liability with regard to the prevention and remedying of environmental damage at European level', Desalination and Water Treatment, Vol. 57, No. 25, pp.11520-11527.

77 Park, M. (2014) A Comparative Study of GMO Labeling and Liability Systems in the US, EU and South Korea: The Circumstances and a Future Potential for Harmonization, theses and dissertations; Faure, M. (2000) 'Product liability and product safety in Europe: harmonization or differentiation?', Kyklos, Vol. 53, No. 4, pp.467-508.

78 Kiss, A. and Shelton, D. (2007) 'Strict liability in international environmental law', George Washington Law Scholarly Commons, No. 2, pp.1131-1151.

79 Article 14(2) of the Directive 2004/35/EC of the European Parliament and of the Council, Official Journal of the European Union (2004).

80 Croley, S.P. and Hanson, J.D. (1991) 'What liability crisis? An alternative explanation for recent events in products liability', Yale Journal on Regulation, Vol. 1, No. 8, pp.1-110.

81 Ackerman, R. (1991) 'Regulation and the law of torts', American Economic Review, Vol. 81, No. 2, pp.54-58.

82 Council Directive 85/374/EEC of 25 July 1985 on the Approximation of the Laws, Regulations and Administrative Provisions of the Member States concerning Liability for Defective Products (1985).

83 Article 4 of the Council Directive 85/374/EEC of 25 July 1985 on the Approximation of the Laws, Regulations and Administrative Provisions of the Member States concerning Liability for Defective Products (1985).

84 In the developing countries perspective, China, India and South Africa are the top most countries to adopt and commercialise GM crops. China and South Africa already in the process of commercialising GM food crops, whereas India is willing to introduce GM food crops for commercialisation soon.

85 Gene Watch UK and Green Peace International, GM Contamination Register (2005).

86 Price, B. and Cotter, J. (2014) 'The GM contamination register: a review of recorded contamination incidents associated with genetically modified organisms (GMOs) 1997-2013', International Journal of Food Contamination, Vol. 1, No. 5, pp.1-13.

87 Genetically Modified (GM) Rice [online] http://irri.org/news/hot-topics/genetically-modifiedgm-rice (accessed 20 December 2016).

88 Price, B. and Cotter, J. (2014) 'The GM contamination register: a review of recorded contamination incidents associated with genetically modified organisms (GMOs) 1997-2013', International Journal of Food Contamination, Vol. 1, No. 5, pp.1-13.

89 Zepeda, J.F. (2006) 'Coexistence, genetically modified biotechnologies and biosafety: implications for developing countries', Am. J. of Agric. Econ., Vol. 88, No. 5, pp.1200-1208.

90 Genetically Modified Organisms Act, 1997 (South Africa); Biosafety Act, 2009 (Kenya).

91 Zepeda, J.F. (2006) 'Coexistence, genetically modified biotechnologies and biosafety: implications for developing countries', Am. J. of Agric. Econ., Vol. 88, No. 5, pp.1200-1208. 
92 Committee on Agriculture (2011-2012) Cultivation of Genetically Modified Food Crops-Prospects and Effects, Ministry of Agriculture, India, 37th Report.

93 Balashanmugam, S.K. et al. (2015) 'Liability aspects related to genetically modified food under the food safety legislation in India', Int'l. J. of Soc., Behav., Educnl., Econ, Bus and Ind. Engineering, Vol. 9, No. 12, pp.4060-4065.

94 Genetically Modified Organisms (Amendment) Act, 2006.

95 De Beer, T. and Wynberg, R. (2018) 'Developing and implementing policy for the mandatory labelling of genetically modified food in South Africa', S. Afr. J. Sci., Vol. 114, No. 7.

96 Section 17 of Genetically Modified Organisms Act, 1997 (Act No. 15 of 1997) Determination of Risks and Liability (South Africa).

97 Section 114 to 119 of the Consumer Protection Act, 2008, Republic of South Africa.

98 Article 20 - Without prejudice to the application of the penalties provided for by this law, those responsible for damage to the environment and to third parties shall be liable, jointly, for full indemnification or reparation, independently of the existence of blame; Article 21 - All actions or omissions which violate the standards set out in this law and in the other relevant legal provisions shall be deemed administrative violations of law no. 11.105 of 2005 (Brazil).

99 Ibid.

100 Wong, A.Y-T. and Chan, A.W-K. (2016) 'Genetically modified foods in china and the United States: a primer of regulation and intellectual property protection', Food Science and Human Wellness, Vol. 5, No. 3, pp.124-140.

101 Kou, J-p. et al. (2015) 'Agricultural GMO safety administration in China', Journal of Integrative Agriculture, Vol. 14, No. 11, pp.2157-2165.

102 Article 47 of the Regulations on Administration of Agricultural Genetically Modified Organisms Safety (China).

103 Cui, K. and Shoemaker, S.P. (2018) 'Public perception of genetically-modified (GM) food: a nationwide Chinese consumer study', NPJ Science of Food, Vol. 2, No. 10, pp.1-8.

104 M/s. Nestle India Limited $v$. The FSSAI and Others, MANU/MH/1937/2015.

105 Section 28 of the Food Safety and Standards Act, 2006.

106 Section 28(1) of the Food Safety and Standards Act, 2006 - If a food business operator considers or has reasons to believe that a food which he has processed, manufactured or distributed is not in compliance with this Act, or the rules or regulations, made thereunder, he shall immediately initiate procedures to withdraw the food in question from the market and consumers indicating reasons for its withdrawal and inform the competent authorities thereof.

107 Section 34(1) of the Food Safety and Standards Act, 2006 - If the designated officer is satisfied that the health risk condition exists with respect to any food business, he may, after a notice served on the food business operator (in this Act referred to as an 'emergency prohibition notice'), apply to the Commissioner of Food Safety for imposing the prohibition.

108 Balashanmugam, S.K. (2018) 'Safety assessment and liability regulations in the context of genetically modified food in the BRICS countries', BRICS Law Journal, Vol. 5, No. 1, pp.27-55.

109 Viljoen, C.D. et al. (2006) 'Detection of GMO in food products in South Africa: implications of GMO labelling', African Journal of Biotechnology, Vol. 5, No. 2, pp.73-82.

110 Balashanmugam, S.K. et al. (2018) 'International trade and GM crops: a comparative analysis of safety regulations and their institutional framework in the South Asian countries', Bio-Science Law Review, Vol. 16, No. 5, pp.231-241.

111 Burgdorfer, B. (2018) Global Hot Spots: South Africa Opens Market to U.S. GMO Corn, Farm Progress, December [online] https://www.farmprogress.com/exports/global-hot-spotssouth-africa-opens-market-us-gmo-corn (accessed 21 June 2019). South Africa Approves 1.3 Million Tons of US GMO Corn Imports (2017) [online] https://www.agweb.com/article/southafrica-approves-13-million-tons-of-us-gmo-corn-imports-blmg/ (accessed 21 June 2019). 
112 Genetically Modified Organisms (Amendment) Act, 2006 of South Africa; Regulations on Administration of Agricultural Genetically Modified Organisms Safety (China)

113 Balashanmugam, S.K. et al. (2015) 'Liability aspects related to genetically modified food under the food safety legislation in India', Int'l. J. of Soc., Behav., Educnl., Econ, Bus and Ind. Engineering, Vol. 9, No. 12, pp.4060-4065.

114 Committee on Agriculture (2011-2012) Cultivation of Genetically Modified Food Crops-Prospects and Effects, 37th Report, Ministry of Agriculture, India.

115 Committee on Agriculture (2011-2012) Cultivation of Genetically Modified Food Crops-Prospects and Effects, 37th Report, Ministry of Agriculture, India.

116 Committee on Agriculture (2013-2014) Cultivation of Genetically Modified Food Crops Prospects And Effects, Ministry of Agriculture, India.

117 Article 5, Paragraph 1 and Paragraph 2 of the Nagoya-Kuala Lumpur Supplementary Protocol on Liability and Redress to the Cartagena Protocol on Biosafety.

118 Union Carbide Corporation vs. Union of India and Others, etc., 1992 AIR 248, 1991 SCR Supl. (1) 251.

119 M.C. Mehta and anr. v. Union of India \& Others, 1987 AIR 1086, 1987 SCR (1) 819.

120 Union Carbide Corporation vs. Union of India and Others, etc., 1992 AIR 248, 1991 SCR Supl. (1) 251.

121 Union Carbide Corporation vs. Union of India and Others, etc., 1992 AIR 248, 1991 SCR Supl. (1) 251.

122 Ibid.

123 Tinker, C. (1992) 'Strict liability of states for environmental harm: an emerging principle of international law', Touro J. Transnat'l. L., Vol. 3, No. 155, pp.155-173.

124 M.C. Mehta and anr. v. Union of India \& Others, 1987 AIR 1086, 1987 SCR (1) 819.

125 [1868] UKHL 1.

126 Parmar, B. and Goyal, A., Absolute Liability: The Rule of Strict Liability in Indian Perspective, Manupatra [online] http://docs.manupatra.in/newsline/articles/Upload/ 2D83321D-590A-4646-83F6-9D8E84F5AA3C.pdf (accessed 19 May 2019).

127 Broughton, E. (2005) 'The Bhopal disaster and its aftermath: a review', Environmental Health, Vol. 4, No. 6, pp.1-6.

128 [1868] UKHL 1.

129 Ministry of Consumer Affairs and Food Distribution (2018) The Consumer Protection Bill, Government of India [online] https://www.prsindia.org/billtrack/consumer-protection-bill2018 (accessed 15 May 2019).

130 Article 39 of the Constitution of India - The State shall, in particular, direct its policy towards securing:

a that the citizens, men and women equally, have the right to an adequate means of livelihood.

Article 41 - The State shall, within the limits of its economic capacity and development, make effective provision for securing the right to work, to education and to public assistance in cases of unemployment, old age, sickness and disablement, and in other cases of undeserved want; Article 42 - The State shall make provision for securing just and humane conditions of work and for maternity relief.

131 Article 47 of the Constitution of India - The State shall regard the raising of the level of nutrition and the standard of living of its people and the improvement of public health as among its primary duties and, in particular, the State shall endeavour to bring about prohibition of the consumption except for medicinal purposes of intoxicating drinks and of drugs which are injurious to health.

132 In order to ascertain the quality of milk and to identify different types of adulteration, the survey was conducted by the Regional Offices of the FSSAI throughout the country. The 
samples were collected and analysed from 33 states. The results revealed that the total conforming samples in conformity to the standards established by FSS Act, 2006 were $31.5 \%$ and non-conforming samples were found to be $68.4 \%$.

133 Writ Petition (C) No. 159 of 2012 filed before the Supreme Court of India.

134 Stockholm Declaration, 1972 was the first attempt to conserve and protect the human environment at the international scenario.

135 Central Act No.29 of 1986, the primary objective of the Act is to provide for the protection and improvement of environment and for matters connected therewith.

136 Section 2(f) of the Environment (Protection) Act, 1986 defines 'occupier' as in relation to any factory or premises, means a person who has, control over the affairs of the factory or the premises and includes in relation to any substance, the person in possession of the substance.

137 Sections 15, 16 and 17 of the Environment (Protection) Act, 1986. (India).

138 Section 15 of the Environment (Protection) Act, 1986 - Penalty for contravention of the provisions of the act and the rules, orders and directions:

1 Whoever fails to comply with or contravenes any of the provisions of this Act, or the rules made or orders or directions issued thereunder, shall, in respect of each such failure or contravention, be punishable with imprisonment for a term which may extend to five years with fine which may extend to one lakh rupees, or with both, and in case the failure or contravention continues, with additional fine which may extend to five thousand rupees for every day during which such failure or contravention continues after the conviction for the first such failure or contravention.

2 If the failure or contravention referred to in Sub-section 1 continues beyond a period of one year after the date of conviction, the offender shall be punishable with imprisonment for a term which may extend to seven years.

139 Act No. 68 of 1986. The significant objective of the Consumer Protection Act, 1986 was to protect the interest and safeguard the rights of the consumers.

140 See generally, Section 2(b) of the Consumer Protection Act, 1986 defines 'Complainant' which means a consumer, voluntary consumer association registered under the Companies Act, 1956 or any other law in force; or a central or state government; Also see, Adinarayana, G. (2015) 'Liability under consumer law in India: a socio-legal analysis', Int'l. J. of Research in Human \& Soc. Stud., Vol. 2, No. 11, pp.13-18.

141 Section 2(f) of the Consumer Protection Act, 1986 defines 'defect' means any fault, imperfection or shortcoming in the quality, quantity, potency, purity or standard which is required to be maintained by or under any law for the time being in force or 15 [under any contract, express or implied, or] as is claimed by the trader in any manner whatsoever in relation to any goods.

142 Unfair and Restrictive Trade Practices - An unfair trade practice includes:

1 making a false statement regarding the quality or standard of a good or service

2 selling of goods not complying with standards

3 manufacture of spurious goods

4 non-issuance of a receipt for a good or service sold

5 refusing to withdraw or refund goods or services within 30 days

6 disclosing personal information provided by a consumer to any other person, The Consumer Protection Bill (2018) [online] https://www.prsindia.org/node/595805/ chapters-at-a-glance (accessed 10 May 2019).

143 Ministry of Consumer Affairs (2018) The Consumer Protection Bill, Food and Public Distribution, Government of India.

144 Patil, A. (2011) A Study on Consumer Protection through Maintenance of Product Safety \& Standards in India, Working Paper Series No. 023, ASIAN L INST.

145 Section 24(2)(c) of the Food Safety and Standards Act, 2006 - gives to the public any guarantee of the efficacy that is not based on an adequate or scientific justification thereof. 
146 Ministry of Consumer Affairs and Food Distribution (2018) The Consumer Protection Bill, Government of India [online] https://www.prsindia.org/billtrack/consumer-protection-bill2018 (accessed 15 May 2019).

147 Ministry of Consumer Affairs, Bill No. 226 of 2015 [online] http://consumeraffairs.nic.in/ writereaddata/CP\%20Bill\%202015.pdf (accessed 20 November 2015).

148 Section 73 of the Consumer Protection Bill, 2015.

149 Subramanian, S.R., Saravanan, A. and Sethu Narayanan, S.R. (2015) 'India and the international biosafety law: a critical legal appraisal of the Biotechnology Regulatory Authority of India Bill, 2013', International Journal of Private Law, Vol. 8, No. 2.

150 See, Article 12(3) Implementation and Relation to Civil Liability, The Nagoya-Kuala Lumpur Supplementary Protocol on Liability and Redress; Components of product liability system has been identified from the Council Directive 85/374/EEC [online] http://eur-lex.europa.eu/legalcontent/EN/TXT/PDF/?uri=CELEX:31985L0374\&from=en (accessed 12 December 2016).

151 Article 9 of the Council Directive 85/374/EEC of 25 July 1985 on the approximation of the laws, regulations and administrative provisions of the Member States concerning liability for defective products - For the purpose of Article 1, 'damage' means:

a damage caused by death or by personal injuries

b damage to, or destruction of, any item of property other than the defective product itself, with a lower threshold of $500 \mathrm{ECU}$, provided that the item of property:

1 is of a type ordinarily intended for private use or consumption

2 was used by the injured person mainly for his own private use or consumption.

152 Mitra, S. (2016) Fixation on Product Approval Has to Go: FSSAI Chief, LIVEMINT, 13 April.

153 Section 3(1)(n) of the Food Safety and Standards Act, 2006.

154 Enforced Vide Notification No. S.O. 1855(E), dated 29th July 2010, w.e.f. 29.07.2010, Food Safety and Standards Act, 2006.

155 Enforced Vide Notification No. S.O. 1855(E), dated 29th July, 2010, w.e.f. 29.07.2010, Food Safety and Standards Act, 2006.

156 Enforced Vide Notification No. S.O. 1855 (E), dated 29th July, 2010, w.e.f. 29.07.2010, Food Safety and Standards Act, 2006.

157 MANU/MH/1937/2015.

158 Enforced Vide Notification No. S.O. 1855 (E), dated 29th July, 2010, w.e.f., 29.07.2010, Food Safety and Standards Act, 2006.

159 Raman, R. (2017) 'The impact of genetically modified (GM) crops in modern agriculture: a review', GM Crops \& Food, Biotechnology in Agriculture and the Food Chain, Vol. 4, No. 8, pp.195-208; Porterfield, A. (2017) 'Is it true there are non long term GMO safety studies', Genetic Literacy Project; Bawa, A.S. and Anilakumar, K.R. (2013) 'Genetically modified foods: safety, risks and public concerns - a review', Journal of Food Science Technology, Vol. 50, No. 6, pp.1035-1046.

160 The eligibility of the designated officers shall be not below the rank of a Sub-Divisional Officer, In-Charge of Food Safety Administration.

161 Such notice is referred to as Improvement Notice defined under Section 32 of the Food Safety and Standards Act, 2006. Enforced Vide Notification No. S.O. 1855(E), dated 29th July 2010, w.e.f. 29.07.2010.

162 Section 34 of the Food Safety and Standards Act, 2006. Enforced Vide Notification No. S.O. 1855 (E), dated 29th July, 2010, w.e.f. 29.07.2010.

163 Enforced vide Notification No. S.O. 1868(E), dated 31st July, 2009, w.e.f. 31.07.2009, Food Safety and Standards Act, 2006.

164 Rylands Vs Fletcher, House of Lords, L.R. 3 H.L. 330 (1868) It is the landmark case to establish a new era of tort law in the United Kingdom in the year 1868. 
165 Section 33 of the Food Safety and Standards Act, 2006. Enforced Vide Notification No. S.O. 1855 (E), dated 29th July, 2010, w.e.f. 29.07.2010.

166 MANU/MH/1937/2015.

$167 \mathrm{M} / \mathrm{s}$. Nestle India Limited v. The Food Safety and Standards Authority of India and Others, Bombay High Court, (13 August 2015). 